\title{
Languages as a Shared Cultural Heritage: the Case of the Greater Iranian Peoples
}

\author{
Mitra Ara. Ph.D. \\ Associate Professor \\ Department of Modern Languages and Literatures \\ San Francisco State University \\ 1600 Holloway Avenue \\ San Francisco, CA 94132, USA
}

\begin{abstract}
This article suggests adopting common approaches in introducing languages and peoples as one social group with shared ancestry, homeland, cultures, and languages. By examining this complex relationship among language, ethnicity, nationality, and how people define themselves culturally through a historical examination of the languages and peoples of the Greater Iran (Central and West Asia) as one social group with shared ancestry, homeland, cultures, and languages, the article further argues that a common approach will help to correct the mis-labeling of and misconceptions about these languages, and encourage greater understanding. The history and materials provided in the article are intended to help illustrate how a better recognition of the past while strengthening present relations among any cultural group, such as the Iranian peoples, can form a peaceful connection for the future.
\end{abstract}

Keywords: Iranian peoples, Ethnic and National Identity, West and Central Asia, Greater Iran, common approaches to language.

\section{Introduction}

Using the Greater Iranian peoples as a case study brings to light the responsibility and importance of adopting and advocating common approaches in introducing languages and peoples as one social group that shares ancestry, homeland, cultures, and languages. As a result of globalization, Iranian peoples have scattered, living both in home countries and in the diaspora. Ironically, this has created a false sense of separation and individualization, resulting in Iranian peoples experiencing discord within their communities, disassociation of the Persian language from other Iranian languages, and a sense of "other-ness" among the same group of Iranian peoples, whether Afghanis, Iranians, Tajiks, Baluchs, Kurds, Lors, or others. This splintering has deprived Iranian peoples of their shared historic, cultural, and linguistic heritage.

The relationship between language, ethnicity, and nationality is complex. How do people define themselves culturally? Often it is based on the language they speak, their heritage language - their "mother tongue"-because they are more comfortable communicating with and relating to those who speak the same language. Language alone, however, does not present the entire culture because languages evolve and are vulnerable to outside influences. As people move or migrate to other countries, their languages move with them and come in contact with other languages, which are influenced by and influence each other. This process has taken place throughout history, along with other influencing forces, such as external contacts, shifting social constructs, and adaptations to a changing world, as Iranians have come and continue to come in contact with peoples who speak non-Iranian languages.

Historically, the term Iranian has always carried ethnic and linguistic value. However, use of the term Iranian is different from the name of the country, which is called Iran, and its peoples who, today, are popularly referred to as Iranians by virtue of their Iranian nationality, not necessarily their ethnicity. Iranians who carry Iranian nationality and speak the national language, the New Persian, one of the many Iranian languages, may be Iranian citizens, but not necessarily Iranian, while people who speak an Iranian language and are not from Iran may be Iranians ethnically. The designation Iranian is therefore applied to both those of Iranian nationality and those of Iranian ethnicity, peoples from Iran or other countries of Greater Iran in Central and West Asia, such as Afghanistan, Ossetia, and Tajikistan. Greater Iran refers to the Iranian Plateau and parts of the neighboring areas encompassing the areas of Central Asia, and South and West Asia, which, historically, have been influenced by Iranian languages and cultures (Frye, 1963, 1993). Iranian as a linguistic classification marks nations or peoples who spoke or still speak Iranian languages. Thus, Iran references all of the geographical territories where Iranian languages are spoken. Further clarifying the terms Iranian Peoples and Iranian, Frye (2006) explains: 
...the term "Iranian" may be understood in two ways. It is, first of all, a linguistic classification, intended to designate any society which inherited or adopted, and transmitted, an Iranian language. The set of Iranianspeaking peoples is thus considered a kind of unity, in spite of their distinct lineage identities plus all the factors which may have further differentiated any one group's sense of self. (p. 321)

Just as Iranians have influenced other cultures, non-Iranian languages and cultures have also influenced Iranians. Today, not all Iranians from the country of Iran are ethnically Iranians-linguistically and ethnically they can be of non-Iranian origins but still carry Iranian nationality. By the same token, Iranian language speakers from countries other than Iran, can be Iranian by ethnicity, such as Afghanis of Afghanistan, Baluchs of Pakistan, Iranis of India and Pakistan, Kurds of Iraq and Turkey, Ossetians of Ossetia, Tajikis of Tajikistan, and others.

The surviving non-Iranian languages that have evolved over time and are still present in and still influencing the Iranian territories are from language families, such as Afro-Asiatic: Semitic (Arabic, Aramaic); Altaic: Turkic; Caucasian: Georgian; Dravidian: Brahui; Neo-Aramaic, spoken by Iranian Jews, Christians, and Mandeans (in Khuzestan), by Kurdish in Iraq and Turkey, Armenians and Georgians (in Azerbaijan and Esfahan), and by Romains in Iran (Qazvin and Khorasan) (Windfuhr, 2006-09, Fortson, 2004).

The name Ērān (Iran) is derived from earlier known terms, airyanəm vaējah (Avestan) and aryānām khshathram (Old Persian), meaning the land/kingdom of the Aryans, and Eränshahr (Middle Persian) with the same meaning first used by the Sasanians. Shared by Indians and Iranians, this self-designation, āryo-'Aryan' (Sanskrit ārya-, Avestan airya-, and Old Persian ariya) is generally translated as exalted one, noble, hospitable. Moreover, some scholars specify that the name ārya can also be found in Ossetic Iron, Scythian Alan, Irish Eire (in Celtic) and is identical with Erān and Irān, and that, considering the wide and early dissemination of the word, Ārya must be the name used for all the early speakers of Indo-European languages. The primary indicators of Aryan identity are not physical or racial, but cultural, such as language, religion, folklore, and tradition (Boyce, 1975, p. 131; Burrow, 1973a, pp. 1-3; Frye, 1963, p. 3; Nichols, 1998, p. 261).

\section{Indo-European/-Iranian}

Historical documents show that peoples who migrated from the Southern Russian Steppes over several millennia and settled in vast regions from India to the Atlantic spoke closely connected languages, which are recognized as the precursors to languages spoken today by half the earth's peoples. These languages, and the peoples who spoke them in the Northwestern Asian continent, are known as Indo-European (Francfort, 1994, p. 10). Over time, the many exchanges and borrowings between multiple cultures have shaped the Indo-European languages (Anthony, 1991, p. 215; Gimbutas, 1991, p. 4; Mallory, 1989, p. 24).

The Indo-European language family is divided into approximately twelve major groups. These branches are Germanic, Celtic, Italic, Baltic, Albanian, Slavic, Greek, Indo-Iranian, Armenian, Phrygian, Tocharian, and Anatolian, including Hittite. Indo-Iranian and Balto-Slavic are marked as the earliest branches (Nichols, 1998, p. 256). The Indo-European language group includes both the speakers of Iranian languages and Iranian peoples. Hence, an Iranian language is any language descended from the Iranian/Iranic parent language, belonging to the Indo-Iranian branch of the IndoEuropean larger family of languages. The Ethnologue's web-based publication (Lewis, Simons, \& Fennig, 2018) tracks languages and the peoples who speak them, offering a complex picture through regularly changing data. A brief examination of the database illustrates the extent of the separation and individuation of peoples, highlighting the challenge of adopting common approaches in introducing languages and peoples as one social group.

People have always moved and those movements have been traced and examined through language. It is helpful to consider briefly the broader shifts of people through the regions.Linguists suggest that in about the $3^{\text {rd }}$ millennium BCE, the Proto-Indo-Iranians drifted apart as part of a broader movement of the Indo-European peoples, such as the Anatolians, Hittites, Tocharians, Phrygians, Armenians, Sarmatians, and Alans into Eurasia and Europe, and across Southern Russia into Central Asia, the Iranian Plateau, and extending as far east as Xinjiang in Western China.

The Iranian plateau is approximately the West Asian geographical expanse from Arabia to Eurasia, including Central Asia, Iran, Afghanistan, and west of the Indus River in Pakistan (Frye, 1980, 2006). Today, the Indo-Iranian language family is comprised of Indic, linguistically also referred to as Indo-Aryan, Iranic, and Nuristāni, of which only the first two, the Indic and the Iranic, were recorded in antiquity. Nuristāni languages are spoken in the eastern province of Nuristan in Afghanistan. The current distribution of Iran differs greatly from its ancient expansion, which included a vast portion of the Eurasian steppe, and Central and South Asia. 
Iranian linguistic division can be chronologically categorized into three periods as early as the $1^{\text {st }}$ millennium BCE: Old Iranian (up to the $4^{\text {th }}$ century BCE, including the language of the Median and Achaemenid dynasties), Middle Iranian (from the $4^{\text {th }}$ to $9^{\text {th }}$ centuries CE, including the language of the Sasanian dynasty and other Iranian nations), and New/Modern Iranian (from the $9^{\text {th }}$ century CE to present, as spoken by several nations in Central and West Asia). The only Iranian language known to occur in all three periods is Persian (Old, Middle, New), the language originally spoken in the province of Pārs (Arabic pronunciation is Fārs).

\section{New/Modern Iranian Languages and Peoples}

Today, the surviving Iranian languages constitute one of the world's major language families, with nearly 150-200 million speakers, (Windfuhr, 2009, p. 1). Iranian languages are spoken in various regions by diverse groups of peoples, and are linguistically categorized as the western group of the Indo-Iranian language family, which is the eastern branch of the Indo-European family of languages.

Similar to the Old and Middle Iranian language classifications, the New/Modern Iranian languages also follow the western and eastern groupings without having any direct geographical correspondence. For example, the Ossetic language of the eastern language group is spoken by the people of Ossetia located in the northwest of the Iranian plateau in the Caucasus. The majority of these languages have various dialects of their own. Moreover, New Iranian literary languages include Persian (Dari, Fārsi, and Tājiki), Pashto, Ossetic, Kurdish, and Baluchi.

The New Persian category, as an official language in Afghanistan, Iran, and Tajikistan, is a descendant of Middle Persian, and is spoken in numerous variations and categorized as a western Iranian language. The Standard New Persian, however, is the literary language taught both inside and outside the home countries. Major variations of the spoken Persian language with different non-Iranian influences are found in all Persian-speaking countries. Since the $16^{\text {th }}$ century, the Tajiki-Persian language, as it is used in Tajikistan and parts of Uzbekistan, has developed differently from the Persian of Iran, as it has been influenced by the Central Asian Turkic language of the Turkmen and Uzbek (Windfuhr, 2009, p. 420).

After the Arab Muslim conquest of the Persian Empire in the $7^{\text {th }}$ century CE, the language, like other aspects of the Iranian culture, went through various processes of transformation. During the Abbasid Caliphates $\left(8^{\text {th }}-13^{\text {th }} \mathrm{CE}\right)$, with the resurgence of Persian national identity $\left(9^{\text {th }}-10^{\text {th }}\right.$ C.E), a form of Persian language known as Persian-Dari (Pārsi-e Dari), originally developed in the Afghanistan and Tajikistan region, became the official literary language of Iranians. The official Persian Pahlavi (Middle Persian) language was gradually replaced by Dari. The name Dari is believed to be an abbreviation of the word Darbāri, meaning the royal court from where the patronage of poetry and literature originated. Hence, Dari became the basis of the New Persian language and its variant dialects. Pahlavi as the language of the western provinces, Pārsi as the language of the province of Pārs, and Khuzi as the language for the southwestern state of Khuzestan continued in practice for a couple of centuries after the Arab Muslim incursion, after which the New Persian became the lingua franca of western Asia, including Asia Minor, and Central and South Asia (Lazard, 1975, pp. 595-632). The Middle Persian Pahlavi language and its writing were in use from the $3^{\text {rd }}$ century CE until the $10^{\text {th }}$ century CE, three hundred years after the $7^{\text {th }}$ century CE Muslim-Arab conquest of Greater Iran.

Beginning from the $8^{\text {th }}$ century CE, New Persian has gone through three stages of development, the early, classic, and modern periods. It has been influenced by, and has influenced many other, non-Iranian languages, such as Armenian, Assyrian, Arabic, Turkic languages, and Indic languages, especially Hindi and Urdu. Beginning in the early $10^{\text {th }}$ century CE, New Persian was used as the literature language of South Asia and Central Asia, and the lingua franca of the eastern realms of the Islamic world.

Languages are also changed by existing in both oral and written forms, further individuating the languages through different scripts and writing systems. Historically, various Iranian writing systems have been used to record Iranian spoken languages. In pre-Islamic periods, major writing systems were Cuneiform and Aramaic and their variants, all of which were used by the Achaemenid, Parthian, Sogdian, Sasanian, and Chorasmian for imperial, secular, and religious recordings. Two other scripts, Manichean and Nestorian, were also used. Manichean was used in the writings of Middle Persian, Parthian, Bactrian, Sogdian, and New Persian, and Nestorian was used in the writings of Christian Sogdian and New Persian. Hebrew was used for New Persian and local dialects, and Arabic was used for New Persian, Chorasmian, Kurdish, Pashto, and Baluchi writings. Brahmi was used for Khotanese, Tumshuqese, and Sogdian writings; Greek for Bactrian writings; Cyrillic for Ossetic, and Tajik writings; Georgian for Ossetic writings; and Latin for Kurdish and Ossetic writings (Windfuhr, 2006, 2009).

In general, New Persian has been written in various scripts, such as Avestan (also called Pazand), Cyrillic, Hebrew (Judeo-Persian), Persian (Perso-Arabic), Manichean, and Syriac. The Hebrew script has been used through the centuries by Iranian Jews for writing, especially Persian, but also other forms of Judeo-Iranian. 
Today most Iranian language speakers have adopted the writing system of their ruling governments. In the case of Afghanistan and Iran, the Perso-Arabic script has been used for over 1,000 years. The Arabic script was adapted by Iranians in place of Middle Persian Pahlavi script, and modified to create a new Perso-Arabic writing system used in New Persian writing as well as in Balochi, Pashto, and many other Iranian Languages spoken in various countries. In Tajikistan, Perso-Arabic was first used, but, in the early $20^{\text {th }}$ century CE, under Soviet domination, the Latin writing system was first adopted, and, later, the Cyrillic, which remains today. The Latin alphabet is also used to write Kurdish language in our modern times.

The languages, oral and written, complicated by varying degrees of the governments' agreement and disagreement, peace and war, further separates peoples who are, culturally, one.

\section{Persian Language}

At present, there are ten variations of New Persian. The three major literary forms are: Afghani-Persian, as one of the two national languages of Afghanistan, the other one being Pashto, which still belongs to the Iranian language family (both languages are written in Persian script); Irani-Persian, as the national language of Iran, written in Persian script; and Tajiki-Persian, as the national language of Tajikistan (written in Cyrillic). The remaining seven variations are Aimaq, (Afghanistan), written in Persian; Bukharic (Israel and Tajikistan), written in Hebrew and Cyrillic; Dzhidi Judeo-Persian (Iran and Israel), written in Persian and Hebrew; Darvazi (Afghanistan and Tajikistan), written in Persian and Cyrillic; Dehwari (Pakistan), written in Persian; Hazaragi (Afghanistan and Pakistan), written in Persian; and Pahlavani (Afghanistan), also written in Persian.

The word "Persian" is the English translation of the name of the language "Pārsi" and should be used when referring to the language in English. Persian is derived from Old Persian Pārsāa, Greek Pérsis, and Latin Persia. Fārsi is the Arabic pronunciation of Pārsi after the province where the language originated in the southwestern Iranian state of Pārs, Arabicized Fārs. Due to the lack of the 'p' phoneme in Standard Arabic, 'P' was replaced by 'F'; thus, Parsī became Fārsi. Therefore, using Fārsi to refer to the Persian language in English is neither good Persian nor correct English. This leads to some of the mis-labeling that is so divisive and problematic for the culture. Similar to English or Spanish languages, different variations are spoken in various countries and are labeled according to the country in which they are spoken, e.g., Welsh English, Australian English, American English, and so forth. Similarly, Persian is one language spoken in different countries and can be referenced similarly, as Afghani-Persian, Irani-Persian, and Tajiki-Persian. Hence, the endonym Fārsi as a Persian word should be used only in the Persian language and not in English or any other non-Persian languages. By observing this practice, along with the ancient Persian language, Persian culture, history, literature, poetry, and its arts are also recognized, appreciated, imparted, and preserved.

In 1935, King Reza Pahlavi, the last monarch of Iran, officially changed the name of the country from Persia to Iran. Yarshater (1989) states:

Had Persia remained the sole name of the country in the English language, no one would have found it necessary to import the unfamiliar and pretentious term Fārsi for Persian in order to show his ignorant pride in the knowledge of the Persian word for Persian. One should not belittle the effect of those ill-informed organizers of Persian courses, film dubbers, translators, leaflet producers, pamphlet writers, and their inept Persian followers who are eager to show off their inside knowledge of the language spoken in a country named Iran and forget that this language has long been legitimately known as Persian. (pp. 62-65)

In the latter part of the $20^{\text {th }}$ century CE, for political reasons, the very same Persian (Pārsi/Fārsi) language came to be referred to as Dari in Afghanistan, Tajiki in Tajikistan, and Fārsi in Iran, and, further, these terms mistakenly entered the English language as the official names of supposedly three different languages, when, in fact, they are all the same New Persian Language. In the case of Afghanistan, "There began a general promotion of the Pashto language at the expense of Fārsi - previously dominant at the educational and administrative level — and the term 'Dari' for the Afghani version of Persian came into common use, being officially adopted in 1958" (Olesen, 1995, p. 205).

As for the ramifications of manipulating and renaming the Persian language, and because of a language reform movement in Iran, Karimi-Hakkak (1998) states:

All this affected translation activities in Persian, seriously undermining the international character of the language. The problem was compounded in modern times by several factors, among them the realignment of Central Asian Persian, renamed Tajiki by the Soviet Union, with Uzbek and Russian languages, as well as the emergence of a language reform movement in Iran which paid no attention to the consequences of its pronouncements and actions for the language as a whole. The result has been a crisis of mutual intelligibility, which marks the impressive volume of translations into the modern Persian of Iran of little use outside Iran's borders. Coupled with the fact that in the last century or so no important translation movement has taken shape 
in Afghanistan or in Persian-speaking Central Asia, the fate of Persian as an international language can be said to stand at a critical juncture at the end of the twentieth century. (p. 518)

Although numerous languages and dialects are spoken in Persian-speaking countries, the influences of the Persian language and culture have created well-founded interconnections and a sense of unity among all Iranian peoples. Frye states "...the Baluch, Turkmen, Armenians, and Kurds, although with bonds to their kinsmen on the other side of borders, are conscious of the power and richness of Persian culture and willing to participate in it" (2006, p. 321).

Today, people have the freedom to define themselves ethnically, linguistically, and nationally any way they choose. However, for academic accuracy in studies of Asia, and of Iranian languages and peoples, and for the preservation of the heritage in addition to political correctness, it is important to remember that not all the Iranians who speak Persian and carry Iranian nationality can be labeled as Persians, such as the Armenians, Assyrians, Arabs, Turks, Uzbeks, and so on. People who may not have Iranian nationality, but may speak a Persian language or another Iranian language as their mother tongue and/or as their national language, may be defined ethnically as Iranian, such as the Afghanis (Persian-Dari speakers in Afghanistan), Pashtuns (Afghans), Hazaras, Pamiris, Aimaqs, Tajiks, Ossetians, Kurds, Lors, and Balochs with speakers in Afghanistan, Iran, Tajikistan, Ossetia, Pakistan, Turkey, Iraq, and several neighboring countries. Now, in the diaspora, individuals ethnically identify themselves using the generic umbrella term "Persian" more often than would be expected, differing from their true ethnic background. The end result is layer upon layer of differentiation through language, history, and politics, coupled with the differentiation of self-identification.

\section{Conclusion}

Not all Iranians are Persian, not all Persian speakers are from Iran, and not all Iranian language speakers are from Iran/Persia. Yet, Persian speakers and other Iranian language speakers from Afghanistan, Iran, Tajikistan, Central and South Asia, Caucasus, Asia Minor, and other parts of the world with varied nationalities may ethnically define themselves as Iranian and/or Persian.

Today, peoples who speak Iranian languages and are defined ethnically as Iranians may come from many different places, and their language may be known by many different names. The majority come from Afghanistan, Iran, and Tajikistan where the New Iranian languages are known as: Persian, locally called P/Fārsi, Dari, Hazari, and Tajiki (Afghanistan, Iran, Tajikistan); Pashto (Afghanistan, Pakistan); Pamiri (Afghanistan, Pakistan); Irani, Pārsi (India, Pakistan); Baluchi (Afghanistan, Iran, Pakistan); Kurdi (Iran, Iraq, Turkey); Gilaki, Mazandarani, Lori (Iran); Talysh (Republic of Azerbaijan, Iran); Yaghnobi (Tajikistan); Ossetic (Ossetia); and some others (Lewis et al., 2014). Yet, they are more connected than many realize.

Iranian languages are an extraordinary resource for the exchange of knowledge, and should be preserved. To do so, it is critical that educators avoid using incorrect terminology and labeling. We must adopt and advocate common approaches in introducing Iranian languages and peoples as one Asian social group that shares ancestry, homeland, cultures, and languages in order to offset the misleading references by commentators, lecturers, and others. The brief history and materials provided here are intended to be shared with others in order to better recognize the past and strengthen present relations among Iranian peoples, thus forming a peaceful connection for the future.

\section{References}

Anthony, D. (1991).The archeology of Indo-European origins, Journal of Indo-European studies 19, 193-222.

Anthony, D. (2001). Persistent identity and Indo-European archeology in the Western Steppes. In C. Carpelan, A. Parpola, \& P. Koskikallio, Early contacts between Uralic and Indo-European: Linguistic and archaeological considerations (pp. 11-35). Helsinki: Suomalais-Ugrilainen Seura.

Boyce, M. (1975a). A history of Zoroastrianism: Vol. I (p. 131). Leiden: E. J. Brill.

Boyce, M. (1979). Zoroastrians: Their religious beliefs and practices. London: Routledge, Kegan and Paul.

Boyce, M. (Ed. and trans.). (1984). Textual sources for the study of Zoroastrianism. Chicago: University of Chicago Press.

Burrow, T. (1937a). The Sanskrit language. New and rev. ed. London: Faber \& Faber.

Erdosy, G. (1995). Language, material culture and ethnicity: Theoretical perspectives. In hisThe Indo-Aryans of Ancient South Asia: Language, material culture and ethnicity (pp. 1-31). Berlin:De Gruyter.

Fairservis, Jr., W. A. (1997). The Harappan civilization and the Rgveda. In M. Witzel (Ed.), Inside the texts, beyond the texts: New approaches to the study of the Vedas (pp. 61-68). Cambridge, MA: Harvard University.

Fairservis, Jr., W. A. (1995). Central Asia and the Rigveda: The archaeological evidence. In G. Erdosy, The IndoAryans of Ancient South Asia: Language, material culture and ethnicity (pp. 206-212). Berlin: De Gruyter.

Fortson, B. W. (2004). Indo-European language and culture: An introduction. Malden, MA: Blackwell. 
Francfort, H. P. (1994). The Central Asian dimension of the symbolic system in Bactria and Margiana, Antiquity 68(259), 406-418.

Frye, R. N. (1963). The heritage of Persia. Cleveland, OH: World Publishing Company.

Frye, R. N. (1993). Iranian identity in ancient times. Journal of the Society for Iranian Studies (26), 1-2, 143-146.

Frye, R. N. (2001). The heritage of Central Asia: From antiquity to the Turkish expansion. $3^{\text {rd }}$ printing. Princeton: Markus Wiener Publishers.

Frye, R. N. (2006). Iran II: Iranian history - Iran V: Peoples of Iran. In E. Yarshater, Encyclopaedia Iranica. Volume XIII, Fascicle 3 (p. 321). New York: Encyclopaedia Iranica Foundation.

Gimbutas, M. (1991). The civilization of the goddess: The world of Old Europe. San Francisco: HarperSanFrancisco.

Gnoli, G. (1980). Zoroaster's time and homeland: A study on the origins of Mazdaism and related problems. Series Minor VII. Naples: Istituto Universitario Orientale.

Harmatta, J. (1992). The emergence of the Indo-Iranians: The Indo-Iranian languages. In A. H. Dani and V. M. Masson, (Eds.). History of civilizations of Central Asia. Volume I (pp. 357-378). Paris: Unesco Publishing.

Hiebert, F. T. (1995). South Asia from a Central Asian perspective. In G. Erdosy, The Indo-Aryans of Ancient South Asia: Language, material culture and ethnicity (pp. 192-205). Berlin: De Gruyter.

Humbach, H. \& Ichaporia, P. R. (Trans.). (1994). The heritage of Zarathushtra: A new translation of his Gāthās. Heidelberg: Universitätsverlag C. Winter.

Karimi-Hakkak, A. (1998). Persian tradition. In M. Baker (Ed.), Routledge encyclopedia of translation studies (pp. 513-522). London: Routledge.

Kellens, J. (2000). Essays on Zarathustra and Zoroastrianism. Trans. and ed. by P. O. Skjærvø. Costa Mesa, CA: Mazda Publishers.

Kuz'mina, E. E. (2007). The origin of the Indo-Iranians. Ed. J. P. Mallory. Leiden, Netherlands: E. J. Brill.

Lazard, G. (1975). The rise of the New Persian language. In R. N. Frye (Ed.). The Cambridge history of Iran, Vol. 4 (pp. 595-632). Cambridge, England: Cambridge University Press.

Lewis, M. P., Simons, G. F., \& Fennig, C. D. (Eds.). (2018). Iranian. In Ethnologue: Languages of the world, 21 st ed. Dallas, TX: SIL International.

Mallory, J. P. (1989). In search of the Indo-Europeans: Language, archaeology and myth. London, England: Thames \& Hudson.

Masica, C. P. (1991). The Indo-Aryan languages. Cambridge, England: Cambridge University Press.

Nichols, J. (1998). The Eurasian spread zone and the Indo-European dispersal. In R. Blench \& M. Spriggs (Eds.). Archaeology and language, II: Archaeological data and linguistic hypotheses (pp. 220-266). London: Routledge.

Olesen, A. (1995). Islam and politics in Afghanistan. New York: Routledge.

Parpola, A. (1995). The problem of the Aryans and the Soma: Textual-linguistic and archeological evidence. In G. Erdosy, The Indo-Aryans of Ancient South Asia: Language, material culture and ethnicity (pp. 353-381). Berlin: De Gruyter.

Renfrew, C. (1987). Archeology and language: The puzzle of Indo-European Origins. Cambridge: Cambridge University Press.

Skjærvø, P. O. (1995). The Avesta as source for the early history of the Iranians. In G. Erdosy, The Indo-Aryans of Ancient South Asia: Language, material culture and ethnicity (pp. 155-176). Berlin: De Gruyter.

Watkins, C. (1990). Studies in Indo-European legal language, institutions, and mythology. In G. Cardona, H. M. Hoenigswald, \& A. Senn (Eds.). Indo-European and Indo-Europeans (pp. 321-354). Philadelphia: University of Pennsylvania Press.

Windfuhr, G. (2006). Iran VI-VII. In E. Yarshater (Ed.), Encyclopaedia Iranica. Volume XIII, Fascicle 4 (pp. 345410). New York: Encyclopaedia Iranica Foundation.

Windfuhr, G. (Ed.). (2009). The Iranian languages. New York: Routledge.

Wittzel, M. (1995a). Early Indian history: Linguistic and textual parameters. In G. Erdosy, The Indo-Aryans of Ancient South Asia: Language, Material Culture and Ethnicity (pp. 85-125). Berlin: De Gruyter.

Witzel, M. (1998). Early Eastern Iran and the Atharvaveda. In Persica (18),86-128.

Yarshater, E. (1993). Persian identity in historical perspective. Journal of the Society for Iranian Studies (26), 1-2, 141142.

Yarshater, E. (1989). Persia or Iran, Persian or Farsi. In Journal of the Society for Iranian Studies (22)1, 62-65.

Zaehner, R. C. (1961). The dawn and twilight of Zoroastrianism. London: Weidenfeld \& Nicolson. 